\title{
A review on ecological degradation, its causes and sustainable development in Delhi, India
}

\author{
Ranjana Saxena \\ Department of Zoology, Dyal Singh College (University of Delhi), Lodi Road, New Delhi \\ 110003, India \\ Rita Rath* \\ Department of Zoology, Dyal Singh College (University of Delhi), Lodi Road, New Delhi \\ 110003, India

\section{Sadhna Gupta} \\ Department of Zoology, Dyal Singh College (University of Delhi), Lodi Road, New Delhi \\ 110003, India \\ Neeraja Sood \\ Department of Zoology, Dyal Singh College (University of Delhi), Lodi Road, New Delhi \\ 110003, India \\ *Corresponding author. Email: ritarath@dsc.du.ac.in
}

\section{Article Info}

https://doi.org/10.31018/

jans.v13i4.2978

Received: September 4, 2021

Revised: November 3, 2021

Accepted: November 7, 2021

\section{How to Cite}

Saxena, R. et al. (2021). A review on ecological degradation, its causes and sustainable development in Delhi, India. Journal of Applied and Natural Science, 13(4), 1294 - 1304. https://doi.org/10.31018/jans.v13i4.2978

\begin{abstract}
Degradation of natural resources and loss of biodiversity (wildlife flora and fauna) is a global problem that affects our society and hampers the economic and social progress of a country towards sustainable development. In developing countries like India, degradation of natural resources is a major threat to socio-economic development. In general, destruction of the environment, biodiversity and nature, has been a major concern in metropolitan cities. Delhi being a metropolitan city and the capital of India, has been facing this problem since 1980's. However, the situation was not that bad then. Over the years, the environmental degradation has not only led to the loss of natural flora and fauna of Delhi city but has also become a cause of great concern because of its impact on the health of the common citizens of Delhi. Modernization, industrialization and overpopulation are key factors responsible for bringing about a drastic change in Delhi's biodiversity and natural resources. Keeping in view their multifarious impacts, the Government of Delhi took some measures to restore the ecosystem of the city. However, we still have a long way to go to bring back the natural flora and fauna of the city, clean air, and the natural resources that have been depleted beyond imagination. Government alone cannot bring about the lost glory of Delhi. Each citizen of Delhi is responsible, and there is a need to join hands together and think in a positive direction to make Delhi a safe living place not only for human beings but also the wildlife that once existed in this majestic city.
\end{abstract}

Keywords: Biodiversity, Ecosystem, Ecological restoration, Environmental degradation, Industrialization, Overpopulation

\section{INTRODUCTION}

The Indian subcontinent has been prospering for about $5,000-6,000$ years (WorldAtlas, 2020). India is one of the oldest civilizations in the world, with a rich cultural heritage and diversity. It is the 7th largest country by land area in the world bounded by the snow-covered Himalayas in the North East, tropical rain forest in the South and Eastern and Western Ghats (National Portal of India, 2017). It extends right up to the Indian Ocean in the South to Arabian sea on the Southwest coast to Bay of Bengal in the Southeast of India covering a total land area of approximately $32,87,263 \mathrm{sq}$. km. (National
Portal of India, 2017).

India is known for its large population size, diverse culture and heterogenous flora and fauna. Overpopulation is of major concern in our country because this has led to unplanned urbanization and modernisation, industrialization and urban migration. People have been migrating to the national capital for different reasons--in search of job/work, better living, monetary gains, better education and career etc., leading to the population explosion in the city. Rapid industrialization and urbanization has resulted in the degradation of forest cover of Delhi, over-exploitation of land, water and our natural resources at a very accelerated rate. 
We, the people of Delhi, are responsible for the deteriorating environment, rapid climate change, loss of natural biodiversity and resources of our city. Remarkably, during the lockdown period of COVID-19 pandemic one could see the animals coming out of their habitat (the habitat of these animals had once been reduced in area by human activities only) into our thickly populated colonies and settlements. These wild animals may be a cause of concern from the epidemiology point of view. They may be carriers of certain diseases that might be transmitted to domestic and other stray animals when they come in contact with them, thereby indirectly transmitting diseases to humans. Thus, in our urban society, the environment is man-made. If remedial measures are not taken soon to restore our ecosystem and natural resources, this is definitely going to affect our economy also.

\section{DELHI- AN OVERVIEW}

Large towns and metropolitan cities are a cause of concern today because of their uncontrolled expansion and improper planning. Delhi is one of the most polluted cities of India today. Delhi has a majestic landscape which has been degraded to a large extent. It is situated at the West bank of river Yamuna, a tributary of the river Ganges (Vernon et al., 2018). The southern part of Delhi is surrounded by the Aravalli hills while the Western part of Delhi has thick hilly ridge area (Vernon et al., 2018). In between the Yamuna river, Aravalli hills and the ridge lies the delta plains (Varsha, 2014). The citizens of Delhi are fortunate to have a luxuriant green forest cover, a rocky hilly area with abundant natural resources and one of the great rivers of Northern India. It has been reported that about $15 \%$ of the land area of Delhi was once occupied by the thick green ridge cover (Varsha, 2014). Earlier, the ridge area was inhabited by an amazing variety of native plant species (trees, shrubs, grasses etc.) and incredibly diverse animal species. Human beings coexisted with a large number of animals like wolves, leopards, foxes, jackals, Rhesus macaque, grey musk shrews, hedgehogs, mongoose, bats, Nilgai, spiny-tailed lizards, insects, large variety of birds etc. in perfect harmony (Kumar, 1997). The flora of Delhi also had a variety of shady trees; like neem (Azadirachta indica), Jamun (Syzygium cumini), ber (Ziziphus mauritiana), mango (Mangifera indica), peepal (Ficus religiosa), bargad (Ficus bengalensis), arjun (Terminalia arjuna) to name a few (Thapliyal, 1987, Press Information Bureau, 2018, Indian State of Forest Report, 2019). Delhi has also been a home for a large number of flowering plants also like gulmohar (Delonix regia), champa (Magnolia champaca), amaltas (Cassia fistula) etc. (Thapliyal, 1987, Press Information Bureau, 2018).

Delhi's ridge and even the Yamuna river have also been an abode for different kinds of fishes, vegetation, weeds, algae and grasses on its banks, attracting migratory birds and other animals like pigs, foxes and hares. It had once been an abode for crocodiles, gharial and testudines (Kumar, 1997). Humans are solely responsible for the degradation of the Yamuna river ecosystem. The ever-increasing population of Delhi which, in turn, led to urbanization and industrialization is responsible for diverting the river water for industrial, agricultural, construction work and domestic use. Resettlement colonies were built on the river banks because of the immigration of labourers from the other states. Dams, embankments and bunds were constructed to prevent the floodwater from entering the houses of the resettlement colonies in the encroached area. This further led to the loss of biodiversity on the banks of river Yamuna and catchment areas. Effluent from industries, pesticides, chemicals and domestic sewage are constantly being dumped in the river Yamuna, thereby polluting it to the extent that our biodiversity has started dwindling rapidly.

The history of Delhi dates back to December 1911, when King George V decided to shift the capital of India from Calcutta to Delhi. The Delhi town planning committee was set up in March 1912 (Delhi: Imperial Capital of British India). Developmental activities began in Delhi and this was the beginning of the degradation of Delhi's landscape and its lush green forest cover. However, even after these developmental activities the situation was not as bad as it is now. A couple of decades ago, the area surrounding this city was mostly agricultural land. The famous Najafgarh drain of Dwarka in the Southwest of Delhi was once a natural drainage system, the largest in Delhi with a lot of aquatic and terrestrial biodiversity around it. It was once an abode of various kinds of birds and animals. Migratory birds used to visit this region in different seasons (Rao, 2020). Today, it is one of the city's most polluted drains with black water and foul smell of various gases. These gases have affected the natural flora and fauna and even several household equipments in the area. The gaseous wastes from the Najafgarh drain have corroded the copper pipes of the air conditioners leading to frequent gas leakage and the televisions, refrigerators, and other electronic gadgets, causing great problems to the residents of Southwest Delhi (Damini, 2016).

In fact, when India hosted the Asian games for the first time in 1982, the extensive-construction work sacrificed the green cover of Delhi. The Asiad Village Complex area once was a green lush area with diverse flora and fauna. A similar ecosystem disruption in Delhi was faced during the Commonwealth games in 2010. The Nizamuddin drain, one of the largest drains of South Delhi, which passes through Dyal Singh College, was covered for the commonwealth games leading to cutting of trees, vegetation, shrubs, grasses, weeds etc. 
Though the area looks very neat and clean, it has been done while compromising our environment. Various natural flora and fauna, chirping birds and animals, even owls, have been replaced by artificial greenery, gardens, trees, flowers etc.

Yamuna was clean and had good vegetation on its banks. Due to increased urbanization and industrialization, the expansion of Delhi in all directions started off leading to mass scale degradation of hilly turf, the ridge area and overexploitation of the Yamuna river water. Despite rapid urbanization, industrialization, cutting of trees, pollution, mining etc, the ridge forest has lost its topographical continuity but is still surviving in small five green discrete areas. These include areas near Delhi University (Northern Ridge comprising 87 hectares), a large green cover near Dhaula Kuan (Central ridge extending from South of Sadar Bazar to Dhaula Kuan, though discontinuous), Sanjay Van (626 hectares of forest cover area near Jawahar Lal University JNU called as South Central ridge), Tughlaqabad (The Southern ridge having a forest cover area of 6200 hectares) and the Nanakpura South Central ridge which is the smallest with only 7 hectares of land area (Bhagidari, 2006, Varsha, 2014). In spite of continued and extensive destruction of the natural habitat, the forest cover area of about 7,784 hectares in Delhi still has the natural flora and fauna (Varsha, 2014, Indian State of Forest Report, 2019). Continued encroachment and destruction of the ridge forced the Lt. Governor of Delhi to declare 25 sites as protected forest areas under the Indian Forest Act 1927 on 10th April 1980 (Varsha, 2014). These areas included the Northern, Central and South-Central ridge areas of Delhi.

In order to conserve the green cover of Delhi, parts of the ridge were transformed into artificial gardens, recreational parks and lakes, such as Buddha Jayanti Park, Lodi Garden, Sanjay Gandhi Park and Mahavir Jayanti Park (Tourism Resources of Delhi, 2021). Though the biodiversity and a perfect balance and harmony of nature have been disturbed in Delhi, yet positively, the existing ridge area sustains a diverse flora and fauna. Immigration and settlement of people near the river bank and ridge area have been a real threat and cause of concern for the fast deteriorating condition of Delhi. Indiscriminate and unplanned development of colonies and random denudation has drastically affected the ecosystem and biodiversity of Delhi. Trees are our lifeline and by cutting off the trees, the oxygen produced and released by them has been drastically affected, and if this continues unabated, then it will be very difficult for our next generation to survive in Delhi. Not only the climate of Delhi will be affected by the indiscriminate cutting of the indigenous trees of Delhi, but it will also have a direct impact on its flora and fauna. Drilling by DMRC (Delhi Metro Railway corporation) and construction of fly-overs and multi-storey buildings is also leaching out the top layers of the soil with essential nutrients. Further, cultivation of cash crops to meet global needs has led to destruction of forest cover depleting six million acres of forest in South East Delhi (Bhattacharyya et al., 2015). This has resulted in leaching of the soil of the essential nutrients and its texture, loss of vegetative cover, unregulated surface runoff, water-table loss, climate change and in general degradation of nature thus making our resources less productive (Bhattacharyya et al., 2015). Various Anthropogenic activities are affecting the landscape, biodiversity and climate of Delhi (Table 1).

With continuous, uninterrupted immigration and urban sprawl, the city of Delhi has extended to Faridabad, Noida, Greater Noida, Ghaziabad and Gurugram; named as National Capital Region (NCR). People travel across the border to work in the NCR and transport has become a major bottleneck making travelling very difficult.

Delhi is subjected to congestion and approximately one -fourth of its population, most of them being immigrants, live in slums and as squatters on the banks of river Yamuna under poor sanitary conditions (Chakrabarti, 2001). They are constantly under the threat of hazards like floods, fires and earthquakes. The increasing rate of immigrants per year has made its population high and uncontrollable. According to the 1991 census, about $80 \%$ of the migrants are from Haryana, Uttar Pradesh, 12\% from Rajasthan, 18\% from Bihar and other States (Chakrabarti, 2001). The uncontrolled immigration, rapid urbanization and industrialization has changed the rural area landscape of Delhi drastically to urban area (Table 2).

As is evident from Table 2, the rural area of Delhi is constantly shrinking and urban area is increasing. The increase in the urban area is obviously because of the increase in the population size. The population statistics data in Table 2 clearly shows that the population of Delhi has drastically increased from 1991 to 2011 (Census of India, 2011, Economic Survey of Delhi, 2018-2019, 2020-2021). The total number of migrants also has increased from 1.78 lakhs in 1991 to 2.8 lakhs in 2011. At the same time, the growth rate during this period has decreased from $51.45 \%$ in 1991 to $21.20 \%$ in 2011 . The decline in the growth rate could be because of better medical facilities, increased literacy rate (compulsory and free education policy for children up to the age of fourteen years), green revolution, improved sanitary conditions, decreased mortality rate and implementation of National Population Policy (Mehta, 2001). Environmentalists have warned that it will become impossible to live in Delhi if the current population growth rate and pollution continue unabated. Ironically, as a result of population growth, the number of vehicles in NCR is increasing exponentially. Delhi has the highest number of vehicles (cars, buses, 
Table 1. Anthropogenic activities causing adverse impact on the landscape, biodiversity and climate of Delhi

\begin{tabular}{|c|c|c|}
\hline Landscape & Biodiversity & Climate \\
\hline Urbanisation and Modernisation & Urbanisation and Modernisation & Urbanisation and Modernisation \\
\hline $\begin{array}{l}\text { Industrialization and commercial } \\
\text { development }\end{array}$ & $\begin{array}{l}\text { Industrialization and commercial } \\
\text { development }\end{array}$ & $\begin{array}{l}\text { Industrialization and commercial } \\
\text { development }\end{array}$ \\
\hline Population growth & $\begin{array}{l}\text { Unplanned felling of indigenous } \\
\text { trees }\end{array}$ & Unplanned felling of indigenous trees \\
\hline $\begin{array}{l}\text { Immigration (global as well as } \\
\text { internal) }\end{array}$ & $\begin{array}{l}\text { Destruction of natural habitat and } \\
\text { green cover areas }\end{array}$ & $\begin{array}{l}\text { Destruction of natural habitat and green } \\
\text { cover areas }\end{array}$ \\
\hline $\begin{array}{l}\text { Unplanned settlement/new } \\
\text { colonies }\end{array}$ & $\begin{array}{l}\text { Unplanned settlement/new } \\
\text { colonies }\end{array}$ & $\begin{array}{l}\text { Extraction of groundwater in excess of } \\
\text { recharge capacity for irrigation, domestic } \\
\text { work and other purposes }\end{array}$ \\
\hline Widening of roads & $\begin{array}{l}\text { Indiscriminate use of agrochemi- } \\
\text { cals (fertilizers and pesticides }\end{array}$ & $\begin{array}{l}\text { Indiscriminate use of agrochemicals } \\
\text { (fertilizers and pesticides }\end{array}$ \\
\hline Construction work & Construction work & Construction work \\
\hline Overuse of natural resources & $\begin{array}{l}\text { Improper agricultural practices and } \\
\text { irrigation }\end{array}$ & Forest fire \\
\hline Quarrying/mining & $\begin{array}{l}\text { Burning of agricultural waste, land- } \\
\text { fill sites and garbage }\end{array}$ & $\begin{array}{l}\text { Burning of agricultural waste, landfill sites } \\
\text { and garbage }\end{array}$ \\
\hline
\end{tabular}

Table 2. Total area and population statistics of Delhi in the last three censuses $(1991,2001,2011)$ (Source: Census of India, 1991, 2001, 2011, Delhi Statistical Handbook, 2014, Economic Survey of Delhi, 2018-2019, 2020-2021)

\begin{tabular}{lllllll}
\hline Census Year & $\begin{array}{l}\text { Rural area } \\
\text { sq. km. }\end{array}$ & $\begin{array}{l}\text { Urban area } \\
\text { sq. km. }\end{array}$ & $\begin{array}{l}\text { Total area of } \\
\text { Delhi sq. km. }\end{array}$ & $\begin{array}{l}\text { Population } \\
\text { in lakh }\end{array}$ & $\begin{array}{l}\text { Migrant in } \\
\text { lakh }\end{array}$ & $\begin{array}{l}\text { Growth rate } \\
\text { in percent }\end{array}$ \\
\hline 1991 & 797.66 & 685.34 & 1,483 & 94.21 & 1.78 & 51.45 \\
2001 & 558.32 & 924.68 & 1,483 & 138.51 & 2.75 & 47.02 \\
2011 & 369.35 & 1113.65 & 1,483 & 167.88 & 2.8 & 21.20 \\
\hline
\end{tabular}

trucks etc.) and the contribution of the vehicular sector in air pollution has increased substantially over the years, thus posing a threat to Delhi's air quality.

The World Health Organization (WHO) has rated Delhi as the fourth most polluted megacity in the world. According to $\mathrm{WHO}$, air pollution is the major cause of environmental health problems and this has to be taken care of on a priority basis (Chopra, 2016, United Nations Environment Programme, 2017). The most common air pollutants in urban cities like Delhi are aerosols (solid and liquid particles suspended in the air), suspended particulate matter (SPM) $\mathrm{PM}_{2.5}$ and $\mathrm{PM}_{10}$, carbon monoxide $(\mathrm{CO})$, sulphur dioxide $\left(\mathrm{SO}_{2}\right)$, oxides of nitrogen ( $\mathrm{NO}$ and $\mathrm{NO}_{2}$ ), lead $(\mathrm{Pb})$ and hydrocarbons. The increase in SPM directly impacts the health of people, causing higher risk of cardiovascular and lung diseases like asthma, bronchitis, cancer, etc. It is very difficult to say what are the main sources of air pollutants in urban megacities like Delhi, but a massive in- crease in the vehicular sector does point to the fact that this is one of the main sources of air pollutants in Delhi and NCR. As per Central Pollution Control Board (CPCB), New Delhi, India, vehicles contribute about 70$80 \%$ of air pollution in megacities (Gulia et al., 2015).

Besides vehicles, rapid increase in industrial sector, waste disposal landfills, sewage treatment plants, waste incinerators, electricity generation, household cooking, open burning of fodder and agricultural waste, burning of landfill etc. are some of the other effects of population growth that are directly contributing towards an increase in air pollution (Bentinck and Chikara 2001, Abdurrahman et al., 2020). These units release carcinogenic and toxic chemicals into the environment, which have a drastic effect on the human health, environment and biodiversity of Delhi.

Until 2000, industrial units were spread over the city in residential and commercial areas which was a major threat to the environment and the people residing near 
Table 3. Major air pollutants, their anthropogenic source, effect on human health and environment (its flora and fauna) (Source: Rizwan et al., 2013, Central Pollution Control Board, 2016, Sarkawt et al., 2020)

\begin{tabular}{ll}
\hline Pollutant & Anthropogenic source \\
\hline & \\
Carbon monoxide & $\begin{array}{l}\text { Incomplete burning of fossil } \\
\text { fuels, Vehicles, burning of } \\
\text { (CO) }\end{array}$ \\
garbage, tyres and plastics
\end{tabular}
garbage, tyres and plastics

Industries, Power plants, Pe-

Sulphur dioxide $\left(\mathrm{SO}_{2}\right)$

Oxides of Nitrogen ( $\mathrm{NO}$ and $\mathrm{NO}_{2}$ )

Lead $(\mathrm{Pb})$

Suspended particulate matter (SPM) $\mathrm{PM}_{2.5}$ and $\mathrm{PM}_{10}$

Hydrocarbons
Burning of ash, fly ash, Power plants, Industries, Cement factories, Construction work
Industries, Power plants, Fertilizer manufacturing unit, Automobiles, sewage treatment plants, burning of garbage

Industrial units-paint and dye industries, Battery plants and smelters, Sewage treatment plants, Waste incinerators, Automobiles

Respiratory disorders, carcinogenic effects: liver attacks, irregular heartbeat,

Carcinogenic effects, irregular heart rhythms, respiratory disorders

Anemia, weakness, kidney and brain damage, Neurological impairment, Reproductive disorder fibrosis, lung cancer, heart

Environment effects/ flora and fauna

Indirectly affects the greenhouse gases and thus have an adverse impact on vegetation

Reacts with water and other pollutants in the air to form aerosols, the particles that fall down as Acid Rain has direct effect on vegetation, damage crops and plants, affects the nature of the soil and its contents, affects aquatic and terrestrial life

Forms aerosols, the particles that fall down as Acid Rain have direct effect on vegetation,

damage crops and plants, affects the nature of the soil and its contents, affects aquatic and terrestrial life, causes necrosis of plants and defoliation,

Air pollution, lead particles can remain in the air, soil and water indefinitely as dust

Reduces visibility, affects the nature of soil and its content, has a direct impact on biodiversity-the stomata of plants can be damaged, respiratory tract of animals and humans is affected

Air pollution, climate change, contributes to greenhouse effect, depletion of ozone layer, reduces photosynthetic ability of plants it. However, the Master Plan of Delhi (National Capital Region Planning Board, 1986) has categorically mentioned that industrial units and factories could no longer be operational from residential areas of Delhi. National Green Tribunal (NGT) directed the Centre and Delhi Government to shut down all these unauthorised and illegal factories and industrial units from residential areas. In November 2000, The Supreme court of India gave a judgement to close down all the polluting industrial units from the residential area (Bentinck and Chikara, 2001). The Delhi government reallocated these in- dustrial units in the outskirts of Delhi away from residential areas. This brought some relief within the city but still did not solve the problem of pollution as the industrial effluents emitted out by these industries are still affecting our environment as much of the particulate matter is being carried back into the city by dust storms and wind. To reduce air pollution, Air quality monitoring stations have been set up in Delhi. Various organizations are involved in this: Central Pollution Control Board (CPCB), Central Pollution Control Committee (CPCC) and System of Air Quality and Weather 
Forecasting and Research (SAFAR).

Delhi has a high level of pollution all year round. It becomes worse in winters from November to January in NCR and Delhi when the farmers burn their agricultural waste and stubble at the border. In addition, in winters, the squatters on the banks of river Yamuna and the slum dwellers burn plastic and tyres to keep themselves warm. This has a direct impact on the air quality of Delhi. The mean Ambient air quality levels of various pollutants in Delhi from 2015 to 2020 are given in Table 4.

As is evident from the table, all pollutants, in the last six years, rose much above the standard prescribed value putting Delhi in an unhealthy high-risk bracket. Howev$\mathrm{er}$, in the year 2020 the mean ambient air quality of all the pollutants has decreased considerably which may be attributed to the frequent complete lockdowns for a long duration because of COVID-19 pandemic with imposed restrictions on vehicular movements, industrial sector etc. (Ritwik et al., 2021). The lockdown started on March 24, 2020. Just after three weeks of lockdown, a decline in the concentration of the major air pollutants like $\mathrm{PM}_{2.5}, \mathrm{PM}_{10}, \mathrm{NO}_{2}, \mathrm{CO}_{2}, \mathrm{SO}_{2}$ was reported in Delhi (Bhat et al., 2021). Similar results were observed by Mahato et al., (2020) in Delhi, reporting a decrease in the greenhouse gases during 25th March to 14th April 2020. Animals could be seen roaming freely in the human settlements, a variety of birds increased in number and so did the aquatic animals (Bhat et al., 2021). However, the changes observed in the quality of air and the biodiversity during the lockdown period is only for a short duration and is not a sustainable way to clean the environment in the long run. Bhardwaj, (2020) observed a slight increase in the National Air Quality Index (NAQI) once there was a relaxation in phase manner in vehicular movement, industrial establish- ments and thermal power plants. These findings clearly suggest that keeping the NAQI under control by keeping a check on the transport sector, thermal power plant and the industrial sector can help in restoring the biodiversity of Delhi. It is not possible to shut down these establishments but definitely alternative ways can be formulated to reduce the pollutants. Thus, for having a long-term effect on the air quality of Delhi, there is a need to have concrete policy changes with strict implementation rules.

\section{EFFECT OF POPULATION EXPLOSION ON THE AGRICULTURE SECTOR}

Fallow lands are decreasing and because of the greater demand of the cash crops, the farmers are sowing crops in the fields more than once in a year without following the agricultural rules. This has led to environmental degradation. Overuse of fertilizers and pesticides has drastically affected the nature of the soil, its content and also the water bodies in NCR and in Delhi in general. Another very important cause of concern is the burning of agricultural waste in NCR and the outskirts of Delhi. This does not allow the dispersal of air pollutants (Awasthi et al., 2011). Dust storms from Rajasthan during the summer months also affect the particulate matter of Delhi. Also, as stated earlier, the squatters on the banks of river Yamuna and the slum dwellers burn plastic and tyres to keep themselves warm in winters. All these factors are seriously threatening the economic and social progress of Delhi.

Our future generations may discover that life support systems have been damaged beyond repair if serious remedial measures are not taken up immediately. There is an urgent need to regenerate and restore the degraded ecosystem of Delhi and NCR. It is the moral

Table 4. Mean Ambient air quality levels of various pollutants in Delhi from 2015-2020 (Source: Central Pollution Control Board (2016) /SAFAR, Delhi Pollution Control Committee (DPCC), System of Air Quality and Weather Forecasting and Research (SAFAR) and Economic Survey of Delhi 2020-2021)

\begin{tabular}{lllllll}
\hline Year & $\begin{array}{l}\mathrm{PM}_{2.5} \\
\left(\boldsymbol{\mu g} / \mathrm{m}^{3}\right)\end{array}$ & $\begin{array}{l}\mathrm{PM}_{10} \\
\left(\boldsymbol{\mu g} / \mathrm{m}^{3}\right)\end{array}$ & $\begin{array}{l}\mathrm{NO}_{2} \\
\left(\boldsymbol{\mu g} / \mathrm{m}^{3}\right)\end{array}$ & $\begin{array}{l}\mathrm{sO}_{2} \\
\left(\boldsymbol{\mu g} / \mathrm{m}^{3}\right)\end{array}$ & $\begin{array}{l}\mathrm{CO} \\
\left(\mathbf{m g} / \mathbf{m}^{3}\right)\end{array}$ & $\begin{array}{l}\text { Hydrocarbons } \\
\left(\boldsymbol{\mu g} / \mathbf{m}^{3}\right)\end{array}$ \\
\hline Standard & 40 & 60 & 40 & 50 & 2 & 5 \\
2015 & 133 & 295 & 71.96 & 17.54 & 1.51 & 4.41 \\
2016 & 137 & 303 & 71.63 & 20.52 & 1.84 & 6.28 \\
2017 & 130 & 277 & 74.01 & 23.28 & 2.07 & 5.20 \\
2018 & 128 & 277 & 50 & 18.61 & 1.52 & 3.10 \\
2019 & 112 & 230 & 48.18 & 14.76 & 1.44 & 4.25 \\
2020 & 101 & 187 & 40.30 & 13.54 & 1.27 & 3.34 \\
\hline
\end{tabular}


Saxena, R. et al. / J. Appl. \& Nat. Sci. 13(4), 1294 - 1304 (2021)

Table 5. Green forest cover area of Delhi (Source: Economic Survey of Delhi 2020-2021)

\begin{tabular}{llll}
\hline S.No. & Year & Green Forest Cover Area in sq. km. & Percentage total area \\
\hline 1. & 1999 & 88 & 5.93 \\
2. & 2001 & 151 & 10.2 \\
3. & 2003 & 268 & 18.07 \\
4. & 2005 & 283 & 19.09 \\
5. & 2009 & 299.58 & 20.20 \\
6. & 2011 & 296.20 & 19.97 \\
7. & 2013 & 297.81 & 20.08 \\
8. & 2015 & 299.77 & 20.22 \\
9. & 2017 & 305.41 & 20.59 \\
10. & 2019 & 324.44 & 21.88 \\
\hline
\end{tabular}

duty of every citizen of Delhi and NCR to check the land degradation, deforestation and loss of biodiversity. In this regard we need to set certain goals.

\section{PRESENT GOALS}

1. There is a need to protect and conserve our natural resources through active involvement of communities and organizations. These organizations and communities can create general environmental awareness and play an active role in inculcating the concept of rational use of the environment and its natural resources among the citizens of Delhi and NCR. Educational Institutions can design small projects and activities in their curriculum that will bring awareness in the upcoming generations and help restore our environment and biodiversity. Schools and Colleges have already taken one step in this direction by having eco-clubs. The adverse effect on the environment and ecosystem by individuals, Institutions and other organizations should be made accountable to the people and the Government. In fact, Institutions and organizations can play a key role in restoring flora and fauna of Delhi. Study tours to biodiversity parks and gardens like Lodhi Garden, Buddha Jayanti park etc., can generate interest among students and they will be able to appreciate mother nature. This would prevent further deterioration of the ecosystem and would help in restoring the lost flora and fauna of Delhi.

2. There is a need to think of making maximum use of alternate sources of energy like solar energy, CNG (Compressed Natural Gas), LPG (Liquified Petroleum Gas) etc. and use natural resources judiciously so that there is minimum impact on the environment.
3. Eco-friendly construction materials and practices should be encouraged to prevent ecological degradation. The common citizen of Delhi can play a major role by generating public awareness and implementing it.

4. Conserve and enhance green cover through the plantation of saplings. Individuals can be encouraged to plant a sapling on important events and occasions instead of giving away bouquets etc. Most importantly, as true citizens of Delhi and NCR we must all comply with environmental legislation. Strict enforcement of laws can prevent environmental destruction. Stringent punishments like imposing big fines and even imprisonment in adverse cases can keep a check on the offenders.

5. To achieve all these, there is an urgent need for an integrated and coordinated Governmental action to come out with a national policy with stringent laws to protect our environment and natural resources. The Government has taken some concrete measures in restoring the lost natural flora and fauna of Delhi and its natural resources. Collectively, efforts are being made to make the environment safe and healthy for wildlife and humans.

\section{STEPS TAKEN BY THE GOVERNMENT IN RESTORING THE ECOSYSTEM OF DELHI}

1. In order to make Delhi look green, the civic authorities are developing potted plants that are to be placed around sports venues, sides of roads on pavements, railway tracks, roundabouts, underbridges, river banks etc. The pillars supporting the flyovers are extensively covered with greenery. In the coming years, the columns of the flyovers and 
bridges, roadsides etc. would portray a complete green cover by natural plantation. This will not only provide a pleasant and soothing view but will also clean the air and help to restore the ecosystem. Planting of saplings and small plantations are encouraged on the sides of the road. The entire stretch on both sides of the Barapullah flyover has very good green pots aesthetically placed.

2. Planting, nurturing, preserving and conserving plants and trees is a deep-rooted practice with historical significance in India. Delhi Preservation of Tree Act 1994 prohibits the cutting of trees (Bhagidari, 2006, Babu et al., 2020). However, rapid modernisation of the infrastructure of Delhi, which includes the building of flyovers and rapid metro rail system, forced the felling of trees. Over 12,800 trees have been cut in Delhi from 2015 to 2018 by MCD (Municipal Corporation of Delhi), NDMC (New Delhi Municipal Council), DDA (Delhi Development Authority), PWD (The Public Works Department) and DMRC ((Delhi Metro Railway corporation) for various projects (Puri, 2018). The cutting of trees was unavoidable, so an amendment was made in the Act according to which 10 saplings have to be planted against one tree felled. The Government distributed free saplings for plantations to bring back the green cover of Delhi. However,

a. Planting saplings is not a solution to felling of trees as it takes several years for a sapling to become a full grown tree.

b. Grazing cattle often destroy the saplings.

c. The local varieties of trees are replaced with nonindigenous ones.

d. Planting trees quite a distance away from where they were cut will not directly impact on improving the city's air quality.

3. The forest department of Delhi, along with the Delhi Development Authority and Delhi University, took up the initiative of pruning the kikar species and planting species of indigenous plants which existed 150 years ago and were native to the Aravalli range to restore the ecosystem of Delhi. The extensive growth of the exotic Mexican species of kikar in the ridge area has encroached upon the space and nutrients of native plant species resulting in the total destruction and elimination of the native species. Vilayati Kikar (Prosopis juliflora) also depletes the groundwater level as its roots go deep into the soil to absorb water from aquifers. The project was initially started on 84 hectares of land (Babu et al., 2020). The restoring and enriching of the native flora will automatically attract different varieties of birds and animal species, restoring Delhi's biodiversity to some extent.

\section{INITIATIVES TAKEN BY GOVERNMENT FOR BIODIVERSITY RESTORATION}

a. The Yamuna Biodiversity park, established near Wazirabad village on the Western bank of river Yamuna, covering approximately 457 acres, has been declared a heritage site. It was the first biodiversity park to have been established by Delhi Development Authority in collaboration with the Centre for Environmental Management of degraded ecosystems, University of Delhi (Babu et al., 2020) with an aim to restore the endangered species of flora and fauna of Yamuna river basin. As one walks around this biodiversity park, wetlands, grassland communities, forest communities, medicinal plants etc., can be seen. This is purely because of the efforts taken by the Government together with NGOs and local people. It will not be wrong to say that soon the animals too would venture around in this biodiversity park. Some of them, like birds and insects, have already been spotted.

b. The Central ridge area was a barren area till 2004 . Commonly it was referred to as Bhatti mines. Once upon a time this area had thick forest cover and vast biodiversity. Extensive mining of sandstone, mica, gravel and china clay was carried out in this ridge area, resulting in its ecological degradation. The groundwater table also decreased. Because of the ever expanding population, encroachment of the area further brought about a total deterioration and devastation of this natural treasure. The Supreme Court has banned mining activities in Aravalli foothills in Gurgaon, Faridabad and Mewat district of Haryana. The Department of Environment and Forest (DOEF) together with the eco-task force of the Army of that region, started the work on protection, restoration and development of this part of the ridge, which has been given the name Asola Bhatti Wildlife Sanctuary. Millions of native saplings of trees, shrubs and grasses were planted in a planned manner (Forest Department, 2010). Lakes around this region which had become dry and barren are now being restored. The flora and fauna of this part of the ridge too is gradually being restored. A $2 \mathrm{~km}$ long natural trail has been made for the people to walk through this biodiversity park and know the facts about the flora, fauna, mother nature and topography of this area.

c. To restore the Natural heritage of Delhi, Delhi Development Authority in 2004 decided to develop a biodiversity park (Aravalli Biodiversity park-a natural reserve) near Vasant Vihar. Today, there are more than 1,000 plant species and a great variety of insect species attracting a large number of birds and other animals in this biodiversity park-about 24 
types of reptiles, including different species of snakes, monitor lizards, etc. Jackals, porcupines, monkeys, Nilgai etc. have been seen here. Trees like dhak or tesu (Butea monosperma), kadamb (Neolamarckia cadamba), bel (Aegle marmelos), safed kikar (Vachellia leucophloea) and doodhi (Wrightia tinctoria) to name a few, are found in this biodiversity park (Ahluwalia, 2021). Besides trees, many varieties of shrubs and herbs can be found.

d. The Ridge area in Delhi has already been declared as a protected area.

e. A sanitary landfill site has recently been converted into a beautiful park-The Indraprastha park. The park has been built over an area of 34 hectares covering about $2.7 \mathrm{~km}$ on the ring road (Bansal, 2014).

f. In August 2001, the use of green fuels like CNG and LPG were recommended to be lead-free. This was made mandatory for public transports in Delhi as a result of which SPM (suspended particulate matter) concentration in the atmosphere has decreased to a certain extent. However, Delhi being the capital of India, it is difficult to keep a check on the vehicles coming from other states.

g. Emission norms were introduced for all vehicles, whether petrol or diesel, driven at the manufacturing level only in 1990 (Ministry of Environment and forests, 2016).

h. Pollution check has been mandatory for all the vehicles that run on the roads of Delhi. Battery operated vehicles are being encouraged to run on roads.

i. In 2017, The National Green Tribunal banned 15 yrs old diesel and 10 year old vehicles in DELHI-NCR. Government also implemented Euro III emission norms in vehicles to keep a check on pollution.

j. The idea of introducing the Rapid Metro System and building flyovers was to decongest Delhi and thus reduce pollution.

k. However, the burning of agricultural waste in NCR and neighbouring areas in winter months and landfill site management are two areas where a lot of work needs to be done. In this sector, there is a lot of scope for researchers to come up with eco-friendly methods of disposing of the agricultural waste in a short period so that the interest of the farmers is safeguarded. The researchers may come out with alternate methods of safe disposal of agricultural waste but the problem is in implementing it. It has to be ensured that farmers accept the new technology, which is not very easy as the farmers have been following the traditional methods for ages.

The concrete measures and initiatives taken by the Government of NCT (National Capital Territory), Delhi has seen a steady rise in the green forest cover area of Delhi since 1999 as is evident from the data given in Table 5.
This is a positive step and if success is achieved in restoring and preserving the green forest cover, it will bring back the natural heritage of Delhi to a large extent.

\section{Conclusion}

Overuse of environmental services has led to ecological imbalance. With the expansion and development of Delhi, the Aravalli hills, the Ridge and the Yamuna river, which had been a pride of Delhi city, started losing its natural biodiversity and glory. Flora and fauna of a particular place is responsible for its healthy environment and ecosystem. Suppose immediate remedial measures are not taken to restore and conserve the biodiversity and natural resources of Delhi. In that case, it may come to a point when there may be complete loss of bioresources, making it difficult for present and future generations to survive in Delhi. Sustainable development is an approach to achieve a balance between our economic, social and ecological needs. The focus of ecological restoration is to initiate and accelerate the recovery of an ecosystem that has been degraded, damaged and destroyed. It can be only be said that the ecosystem is restored when all the biotic and abiotic components are present in sufficient quantities for the plants, animals and humans to live in harmony. A healthy ecosystem and natural habitat can decrease the effect of parasites and pathogens on humans and other animals and thus save us from the misery of diseases. Gaining knowledge about our environment, its deteriorating condition and finding ways to improve our deteriorating environment and restore flora and fauna of Delhi is one very important aspect, but the need of the hour is to ensure its implementation. Unless the implementation part is ensured, it cannot bring back the lost glory of Delhi in terms of environment, diversity of flora and fauna, natural resources and health.

\section{ACKNOWLEDGEMENTS}

Ranjana Saxena, Rita Rath, Sadhna Gupta and Neeraja Sood acknowledge Dyal Singh College, University of Delhi for its constant support, motivation and encouragement throughout the period of writing this paper.

\section{REFERENCES}

1. Abdurrahman, M.I., Chaki, S. \& Saini, G. (2020). Stubble burning: Effects on health and environment, regulations and management practices. Environmental Advances. 2, 100011. https://doi.org/10.1016/j.envadv.2020.100011

2. Ahluwalia, I. (2021) Restoring Delhis environment: The Indian Express https://indianexpress.com/article/opinion/ columns/restoring-delhis-environment/: (Accessed on August 17, 2021) 
3. Awasthi, A., Agarwal, R., Mittal, S.K., Singh, N., Singh, K. \& Gupta, P.K. (2011). Study of size and mass distribution of particulate matter due to crop residue burning with seasonal variation in rural areas of Punjab, India. J. Environ. Monit, 13(4), 1073-81 https://doi.org/10.1039/C1EM10 019J

4. Babu, C.R., Vidyarthi, A.K., Biswas, M.k., Ahuja, R. \& Singh, S. (2020). Guidelines for setting up of biodiversity parks in floodplains of rivers of India, including river ganga. Submitted to National Green Tribunal Principal Bench, Central Pollution Control Board, New Delhi. Retrieved from https://cpcb.nic.in/openpdffile.php?id=TmV3c0Z pb GVzLzgzXzE1ODk1MzQyMzBfbWVkaWFwaG90bzl1 NDUucGRm (accessed the site on 31st July 2021)

5. Bansal, K. (2014). Energy from Mounds of Waste, Science Reporter, June 2014 Retrieved from http:// nopr.niscair.res.in/bitstream/123456789/28946/1/SR\% 2051\%286\%29\%2026-30.pdf

6. Bentinck, J. \& Chikara, S. (2001). Illegal factories in Delhi: the controversy, the causes, and the expected future. International Workshop, Network-Association of European Researchers on Urbanisation in the South (N-AERUS) and European Science Foundation (ESF), Leuven and Brussels, Belgium 23-26 https://www.ucl.ac.uk/dpuprojects/drivers_urb_change/urb_economy/pdf_infor_e cono/ESFN_AERUS_Bentinck_Illegal\%20factor.pdf

7. Bhagidari, (2006). Towards Greener Delhi. Department of Environment and Forests, Government of National Capital Territory of Delhi. Retrieved from http://web.delhi.gov.in/ wps/wcm/connect/200195004eff00eb885eacb60aeecb21/ TGD.pdf?MOD=AJPERES\&Imod=\%E2\%88\% 92332197946\&CACHEID=2001950 (accessed the site on 10th August, 2021)

8. Bhardwaj, S. (2020). Lockdown reduced pollution in Delhi temporarily, long term needs policy changes. IndiaSpend. Retrieved from https://www.indiaspend.com/lockdownreduced-pollution-in-delhi-temporarily-long-term-reliefneeds-policy-changes/ (accessed the site on 12th August, 2021)

9. Bhat, S.A., Bashir, O., Bilal, M., Ishaq, A., Dar, M.U.D., Kumar, R., Bhat, R.A., Sher, F. (2021). Impact of COVID related lockdowns on environmental and climate change scenarios. Environ Res., 195, 110839. https://doi.org/10.1 016/j.envres.2021.110839

10. Bhattacharyya, R., Ghosh, B.N., Mishra, P.K., Mandal, B., Rao, C.S., Sarkar, D., Das, K., Anil, K.S., Lalitha, M., Hati, K.M., Franzluebbers, A.J. (2015). Soil degradation in India: Challenges and potential solutions. Sustainability, 7 (4), 3528-3570. https://doi.org/10.3390/su7043528

11. Census of India (2011) http//www.censusindia.gov.in/2011 -prov-results/data-files/delhi/2-PDF-paper-1-major-trends44-59.pdf

12. Central Pollution Control Board (2016). Air pollution in Delhi: An Analysis. Central Pollution Control Board, Supported by the Ministry Of Environment, Forests and Climate change, Government of India. Retrieved from http:// cpcbenvis.nic.in/envis_newsletter/air\%20pollution\%20in\% 20delhi.pdf

13. Chakrabarti, P.G.D. (2001). Delhi's Ongoing Debate on Informal Settlements and Workplaces -Issues of Environmental Jurisprudence. International Workshop on Coping with informality and illegality in human settlements in de- veloping cities. Network-Association of European Researchers on Urbanisation in the South (N-AERUS) and European Science Foundation (ESF). Leuven and Brussels, Belgium. Retrieved from https://www.ucl.ac.uk/dpuprojects/drivers_urb_change/urb_infrastructure/pdf_land\% 20tenure NAERUS_ESF_chakrabarti_Delhi_Inf ormal_Se ttlements.pdf

14. Chopra, R. (2016). Environmental Degradation in India: Causes and Consequences. International Journal of Applied Environmental Sciences, 11(6), 1593-1601. https:// www.ripublication.com/ijaes16/ijaesv11n6_21.pdf

15. Damini, N. (2016). A drain on the pocket, every which way. The Hindu, updated 26th Oct. 2016. Retrieved from https://www.thehindu.com/news/cities/Delhi/A-drain-on-the -pocket-every-which-way/article11811847.ece (accessed the site on 22nd Aug. 2021) Delhi: Imperial Capital of British India. Retrieved from https://indianculture.gov.in/ stories/delhi-capital-british-india

16. Delhi Statistical Handbook (2014). Directorate of Economics and Statistics: Government of NCT of Delhi 2014. www.des.delhigovt.nic.in

17. Economic Survey of Delhi (2018-2019). Demographic profile. Retrieved from http://delhiplanning.nic.in/sites/ default/files/2\%29\%20Demographic\%20Profile.pdf Economic Survey of Delhi 2020-2021 http://delhipl anning.nic.in/sites/default/files/8.\%20Environment.pdf

18. Forest Department (2010). Retrieved from http:// forest.delhigovt.nic.in/wps/wcm/connect/doit_forest/Fore st/Home/Forests+Management/ECO+Task+Force, October 2000

19. Gulia, S., Nagendra, S.M.S., Khare, M., Khanna, I. (2015). Urban air quality management -A Review. Atmospheric Pollution Research, 6(2), 286-304. https://doi.org/10.5094/ APR.2015.033

20. Indian State of Forest Report (2019). Delhi. Forest Survey of India. Retrieved from https://fsi.nic.in/isfr19/vol2/isfr2019-vol-ii-delhi.pdf

21. Kumar, A. (1997). Fauna of Delhi. Zoological Survey of India, Dehradun, Government of India. Retrieved from http://faunaofindia.nic.in/PDFVolumes/sfs/037/index.pdf

22. Mahato, S., Pal, S., Ghosh, K.G. (2020). Effect of lockdown amid COVID-19 pandemic on air quality of the megacity Delhi, India. Sci. Of The Total Environ. 730, 139086.

23. Mehta A.-C. (2001). An analysis of Census 2001 Statespecific Population Data. http://www.educationforallini ndia.com/page159.html (accessed the site on 14th Aug. 2021)

24. Ministry of Environment and forests (2016). White paper on pollution in Delhi with an action plan. Ministry of Environment and Forests, Government of India. Retrieved from http://urbanemissions.info/wp-content/uploads/docs/ India-1997-CPCB-White-Paper-on-Delhi-Air-Pollution.pdf

25. National Capital Region Planning Board (1986), Delhi Master Plan 2001. New Delhi

26. National Portal of India, (2017) Retrieved Feb. 4, 2017, https://web.archive.org/web/20170204103447/https:// india.gov.in/india-glance/profile (accessed the site on 27th July 2021)

27. Press Information Bureau (2018). Native tree species Press Information Bureau, Government of India, Ministry of Environment, Forest and Climate change. Retrieved on Aug. 3, 2018, https://pib.gov.in/Pressreleaseshare.aspx? 
$P R I D=1541596$

28. Puri, H.S. (2018). Delhi Tree Cutting. Business Standard. Retrieved from https://www.business-standard.com/article/ current-affairs/over-12-000-trees-cut-in-delhi-for-govtprojects-in-last-3-years-govt-118080901552_1.html

29. Rao, R. (2020). Najafgarh jheel-saga of a forgotten river. SANDRP (South Asia Network on Dams, Rivers and People). Retrieved from https://sandrp.in/2020/09/16/ najafgarh-jheel-saga-of-a-forgotten-river/ (accessed the site on 18th Aug. 2021)

30. Ritwik, N., Pandya, K., Luis, A.J., Sengupta, R. \& Kotha, M. (2021). Positive effects of Covid -19 lockdown on air quality of Industrial cities (Ankleshwar and Vapi) of Western India. Scientific reports, 11(4285). https:// doi.org/10.1038/s41598-021-83393-9

31. Rizwan, S.A., Nongkynrih, B. \& Gupta, K.S. (2013). "Air pollution in Delhi: Its Magnitude and effects on health". Indian J Community Med., 38(1), 4-8. doi: 10.4103/09700218.106617

32. Sarkawt, M.L.H., Prashant, K., Roy M.H., William, J. B., Khare, M., Mishra, S., Namdeo, A., Sokhi, R., Goodman, P., Sharma, C. (2020). Four year assessment of ambient particulate matter and trace gases in the Delhi- NCR region of India. Sustainable Cities and Society, 54: 102003 https://doi.org/10.1016/j.scs.2019.102003

33. Thapliyal, U. P. (1987). Gazetteer of Rural Delhi https:// www.indianculture.gov.in/gazettes/gazetteer-rural-delhi

34. Tourism Resources of Delhi (2021). Retrieved from http:// ncrpb.nic.in/pdf_files/ToursimResourcesofDelhi.pdf (accessed the site on 14th Aug. 2021)

35. United Nations Environment Programme(2017). Towards a Pollution-Free Planet. United Nations Environment Programme, Nairobi, Kenya. Retrieved from https:// wedocs.unep.org/bitstream/handle/20.500.11822/21800/ UNEA_towardspollution_long\%20version_Web.pdf? sequence $=1 \&$ isAllowed=y

36. Varsha (2014). The Delhi ridge. In: Sinha, G.N. (Ed.). An Introduction to the Delhi Ridge (pp. 1-28) Department of Forests \& Wildlife, Govt. of NCT of Delhi, New Delhi. http://forest.delhigovt.nic.in/wps/wcm/connect/1e22 5780 43fa6dcba014e23e3c4139c7/Delhi_Ridge_Book-Sinha\% 2C+G.N.+\%28Ed.\%29+\%282014.pdf?MOD=AJPERE $S \& I m o d=-804673140 \& C A C H E I D=1 e 22578043 f a 6 d c b a$ $014 \mathrm{e} 23 \mathrm{e} 3 \mathrm{c} 4139 \mathrm{c} 7$

37. Vernon, R., Sundaram, K.V. \& Rao, V. (2021). "Delhi". Encyclopedia Britannica, Retrieved Sep. 3, 2021, https:// www.britannica.com/place/Delhi (Accessed the site on 20th Aug 2021).

38. WorldAtlas (2020). The World's oldest civilizations. Retrieved from https://www.worldatlas.com/articles/10-of-the -world-s-oldest-civilizations.html (Accessed the site on 28.7.2021) 